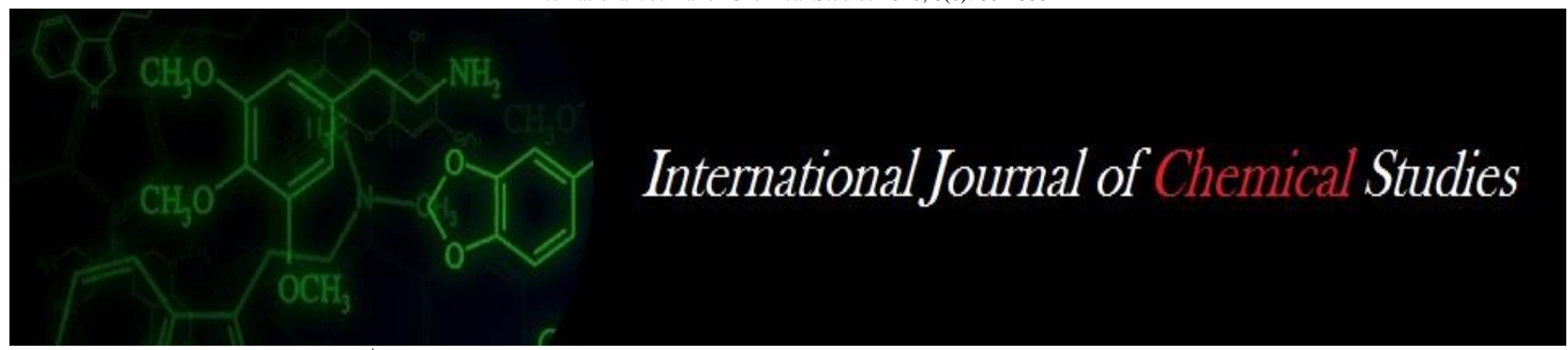

P-ISSN: 2349-8528

E-ISSN: 2321-4902

www.chemijournal.com

IJCS 2020; 8(6): 882-888

(C) 2020 IJCS

Received: 23-08-2020

Accepted: 17-10-2020

Jyoti Choudhary

Department of Veterinary

Microbiology and Biotechnology,

College of Veterinary and Animal

Sciences, RAJUVAS, Bikaner,

Rajasthan, India

\section{SK Kashyap}

Department of Veterinary

Microbiology and Biotechnology,

College of Veterinary and Animal

Sciences, RAJUVAS, Bikaner,

Rajasthan, India

\section{Multiplex polymerase chain reaction for identification of bovine mastitis associated pathogens}

\author{
Jyoti Choudhary and SK Kashyap
}

DOI: https://doi.org/10.22271/chemi.2020.v8.i6m.10879

\begin{abstract}
The present study was focused on the development of a sensitive multiplex polymerase chain reaction (mPCR) for rapid detection of mastitis associated pathogens directly from milk samples. A total of 40 mastitic milk samples were processed for isolation and identification of pathogens which were mentioned below by conventional method and compared it with mPCR. The prevalence of bacterial isolates in conventional detection were found to be 20 (50\%) Staphylococcus aureus, 10 (25\%), Streptococcus agalactiae, 9 (22.5\%) Klebsiella pneumoniae and 8 (20\%) Escherichia coli, respectively. In mPCR all culture-positive samples were detected for the corresponding bacteria but additional numbers of (i.e. $5 S$. aureus, $7 \mathrm{~S}$. agalactiae, 2 E.coli, and $4 \mathrm{~K}$. Pneumoniae) isolates were also detected by $\mathrm{mPCR}$ which were culture-negative. The target sequence for primer designing were the different gene i.e. vicK gene $(S$. aureus), atr gene (S. agalactiae), barA gene (K. pneumoniae) and uidA gene (E. coli). It was concluded that, Staphylococcus aureus appeared as the most prevalent organism responsible for causing mastitis in cattle. Furthur, the results suggested that MPCR was significantly more sensitive than culture detection. A multiplex PCR could be used as an efficient tool for detecting pathogens of mastitis with high accuracy, sensitivity and in a short period of time.
\end{abstract}

Keywords: Bovine mastitis, bacteria, conventional method, diagnosis, multiplex PCR

\section{Introduction}

Bovine mastitis is devastating disease affecting both human and animal health associated with economic losses due to high morbidity, reduced milk production, discarded milk, increased antimicrobial resistance of the organisms in animals along with cost of veterinary treatment (Awale et al., 2012) ${ }^{[3]}$. Mastitis is a multi-etiological complex disease, characterized by inflammation of the parenchyma of mammary glands and changes in physical, chemical, bacteriological characteristics of milk, pathological transformation in glandular tissues (Radostits et al., 2000) ${ }^{[21]}$. Though various wide spectrums of pathogens have been identified as causative agents of mastitis but some major bacterial species are responsible i.e. S. aureus, S. agalactiae, K. pneumoniae and E. coli (Riffon et al., 2001 and Bannerman et al., 2003) [23, ${ }^{5]}$. In most clinical laboratories, identification methods are based on the microbiological culture of milk, antimicrobial sensitivities and biochemical tests on the bacterial isolates. However, there are several disadvantages associated with microbiological culture i.e. it is limited by the dynamic nature of infections. Milk culture may yield no bacteria from truly sub-clinically infected glands due to the presence of very low numbers of pathogens when samples are collected. Negative cultures may also result due to various factors such as residual therapeutic antibiotics or presence of leukocytes with high Somatic Cell Count in milk. Moreover, the microbiological culture of milk is time-consuming. Species identification by standard biochemical methods requires more than $48 \mathrm{~h}$ to complete. Due to the limitations of cultural methods, DNA sequence-based molecular methods have been gaining much attention with an approach for species identification (Cremonesi et al., 2009; Zadoks and Watts, 2009) ${ }^{[7,29]}$ and genome sequences of these pathogens are utilized to develop rapid, sensitive and specific nucleic acid-based testing methods such as mPCR assay which can be used for detection of more than one pathogen in single PCR reaction enhancing early detection of mastitis. The identification of bacteria at the species level in MPCR is based on the amplification of a conserved house-keeping gene sequence, which is highly conserved within the species, but variable between species.
Corresponding Author: Jyoti Choudhary Department of Veterinary Microbiology and Biotechnology, College of Veterinary and Animal Sciences, RAJUVAS, Bikaner, Rajasthan, India 
These regions are amplified by primers designed from such conserved gene for selected pathogen like vicK gene for $S$. aureus (Liu et al., 2007) ${ }^{[16]}$, atr gene for $S$. agalactiae (Munari et al., 2012) ${ }^{[18]}$, BarA gene for K. pneumonia and uidA gene for $E$. coli (Martins et al., 1993) ${ }^{[17]}$ respectively.

The aim of present study was to develop a rapid and early detection method which focused on the simultaneous detection of the pathogens of mastitis directly from mastitic milk i.e. S. aureus, S. agalactiae, K. pneumonia and E.coli through multiplex PCR.

\section{Material and Methods}

\section{Source of milk samples}

A total of forty milk samples were collected from cattle showing symptoms of (clinical and subclinical) mastitis confirmed by the California Mastitis Test. The samples were collected from the Veterinary Clinical Complex and dairy farms in and around the Bikaner city, Rajasthan, India. These samples were collected before milking using standard procedures described by the National Mastitis Council (Oliver et al., 2004) ${ }^{[19]}$.

\section{Isolation and identification of bacteria \\ a) Culture characteristics}

The milk samples were subjected to aerobic cultivation. Each milk sample was inoculated in nutrient broth overnight and then streaked on nutrient agar followed by overnight incubation at $37^{\circ} \mathrm{C}$. Bacterial colonies were closely observed for their morphology, colour and consistency. Gram's staining was used as primary identification test and these presumptive colonies were streaked on Mannitol salt agar (MSA), Edward's medium agar, MacConkey agar and Eosin methylene blue agar (EMB) plates, for isolation of $S$. aureus, S.agalactiae, $K$. pneumoniae and $E$. coli, respectively. These agar plates were incubated for 24 hours at $37{ }^{\circ} \mathrm{C}$ under aerobic condition. The growth was examined for the colonial morphology, fermentation, pigment production and other characteristics.

\section{b) Biochemical characteristics}

Cultures were subjected to different primary biochemical tests viz. Catalase test, Oxidase test, Oxidation-Fermentation test and motility test for all isolates. Isolates identified presumptively as $S$. aureus were confirmed by carried out tube coagulase test using human plasma, mannitol fermentation test, DNase test, haemolytic properties and fermentation of different sugars whereas $S$. agalactiae subjected for growth on Edward's medium, Christie, Atkins, and Munch-Petersen (CAMP) test, hydrolysis of esculin, Arginine hydrolysis test, haemolytic properties on blood agar and Voges-Proskauer test. Gram-negative isolates such as $K$. pneumoniae and E. coli were evaluated by their biochemical reactions on the following: Growth on Mac-Conkey agar, EMB agar, IMViC tests, growth on Triple Sugar Iron agar, Sugar fermentation tests, Urease test, Nitrate reduction test, and utilization of lysine, etc.

\section{3) DNA extraction directly from mastitis milk samples}

All the samples were exposed to extraction of DNA directly from mastitis milk. DNA extraction directly from milk was carried out using the method Phenol-Chloroform Extraction described by Phueketes et al. (2001) [20] with certain alterations. The integrity of DNA was checked by gel electrophoresis used $1.5 \%$ agarose whereas, DNA quantification was carried out by spectrophotometric measurements. The quantified DNA was diluted to a final concentration of this $25 \mathrm{ng} / \mu \mathrm{l}$ in Tris-EDTA (TE) buffer.

\section{4) Desining of oligonucleotide primers}

PCR primers were designed from using highly conserved housekeeping genes included vicK gene for $S$. aureus (Liu et al., 2007) [16], atr gene for S. agalactiae (Munari et al., 2012) ${ }^{[18]}$, BarA gene for $K$. pneumoniae and uidA gene for $E$. coli (Martins et al., 1993) ${ }^{[17]}$. The sequence of primer, target gene, and product size are summarized in Table 1. All primers had similar annealing temperatures, which is essential for multiplex PCR production. These primers were synthesized by Primer3 software. The Insilico PCR tool was used to predict primer location, orientation, length of each amplicon and ability of primers to amplify particular species (Specificity and sensitivity). Then MFEprimer-2.0 software was used for checking possible dimer formation in between inter and intra primer in multiplex PCR. (Qu et al., 2012) ${ }^{[21] .}$ To establish a combination of sets of primers for multiplex PCR, similar Tm values was predicted by the Oligo analyzer tool. All these primers were resuspended to a final concentration of $100 \mu \mathrm{M}$ in deionized autoclaved water.

Table 1: Primers used for amplification of Staphylococcus aureus, Streptococcus agalactiae and Escherichia coli DNA in bovine milk samples by multiplex-PCR

\begin{tabular}{|c|c|c|c|c|c|}
\hline Agent & Target & Primers & Sequences (5'-3') & PCR product size(bp) & Annealing temp. \\
\hline \multirow{2}{*}{ S. aureus } & \multirow{2}{*}{ Vick gene } & js SA F & CAGACCGTCGTGGACGTATT & \multirow{2}{*}{264} & \multirow{8}{*}{$58^{\circ} \mathrm{C}$} \\
\hline & & js SA R & TCACGTCATGTAACACAGCGA & & \\
\hline \multirow{2}{*}{ S. agalactiae } & \multirow{2}{*}{ Atr gene } & jsStrAg F & CCCTTCTGGCTCTGGTAAGTC & \multirow{2}{*}{304} & \\
\hline & & jsStrAg R & TGCTGGATAAGCATTAGCCTTCT & & \\
\hline \multirow{2}{*}{ K.pneumoniae } & \multirow{2}{*}{ barA gene } & js $\mathrm{KN} \mathrm{F}$ & GATGGGCGGGGATATTTCGT & \multirow{2}{*}{555} & \\
\hline & & js KN R & TTCAGGTTAGCCGGGTTGTC & & \\
\hline \multirow{2}{*}{ E.coli } & \multirow{2}{*}{ uidA gene } & js $E C F$ & TACCGACGAAAACGGCAAGA & \multirow{2}{*}{119} & \\
\hline & & jsECR & CGGTGATATCGTCCACCCAG & & \\
\hline
\end{tabular}

\section{5) Multiplex PCR amplification and analysis}

The reaction for multiplex PCR carried out in a final volume of $25 \mu \mathrm{l}$ consisted of $5.0 \mu \mathrm{l} 5 \mathrm{X}$ Go Taq ${ }^{\circledR}$ Flexi buffer, $3.0 \mu \mathrm{l}$ $\mathrm{MgCl} 2(25 \mathrm{mM}), 4 \mu \mathrm{l}$ primer-F(10 $\mathrm{pM} / \mu \mathrm{l})(1 \mu \mathrm{l}$ of individual primer), $4 \mu \mathrm{l}$ primer-R (10 $\mathrm{pM} / \mu \mathrm{l})(1 \mu \mathrm{l}$ of individual primer $), 1$ $\mu \mathrm{dNTP}(25 \mathrm{mM}$ each $), 0.25 \mu \mathrm{lTaq}$ DNA polymerase $(5 \mathrm{U} / \mu \mathrm{l})$, $3 \mu \mathrm{l}$ template DNA $(30 \mathrm{ng} / \mu \mathrm{l})$ and $4.75 \mu \mathrm{l}$ nucleus free water. The pre denaturation at $96^{\circ} \mathrm{C}$ for 5 min was applied. A total of
35 PCR cycles were run under the following conditions: denaturation at $94^{\circ} \mathrm{C}$ for $1 \mathrm{~min}$, annealing at $58^{\circ} \mathrm{C}$ for $1 \mathrm{~min}$, extension at $72^{\circ} \mathrm{C}$ for $1 \mathrm{~min}$., final extension at $72^{\circ} \mathrm{C}$ for 10 min, and PCR products were stored at $4^{\circ} \mathrm{C}$. Amplification product were electrophoresed at $100 \mathrm{~V} / \mathrm{cm}$ for 1 hour in $1.5 \%$ agarose gel prepared in 1.0XTBE buffer containing $0.5 \mathrm{ng} / \mathrm{ml}$ ethidium bromide and visualized by ultraviolet light trans illumination (UVP Gel Doc Bio imaging System). 


\section{Results and Discussion}

\section{Conventional Microbiological Analysis}

Conventional determination was conducted for the above mentioned bacterial pathogens on the basis of cultural and biochemical identification. Milk samples collected from mastitis cases and examined bacteriologically, out of 40 samples, $27(67.5 \%)$ was yielded at least one of the selected target pathogens. A total 47 bacterial isolates have been identified; S. aureus, S. agalactiae, $K$. pneumoniae, and E. coli were recovered in percentage of 50, 25, 22.5 and 20 respectively. It was concluded that, Staphylococcus aureus appeared as the most prevalent organism responsible for causing mastitis in cattle. Kurjogi et al., (2011) ${ }^{[14]}$ also reported that major pathogens isolated from the milk samples were S. aureus and S.agalactiae. The prevalence of Staphylococcus species might be due to the incomplete milking, painful lesions or any wounds on the outer surface of the udder.

Staphylococcus aureus:- Preliminary biochemical characterization of all 20 isolates of S. aureus revealed characteristic growth pattern on mannitol salt agar (MSA) fermenting mannitol and produced characteristics golden yellow colonies, and showed grapes like appearance under microscope after Gram staining (figure 1).

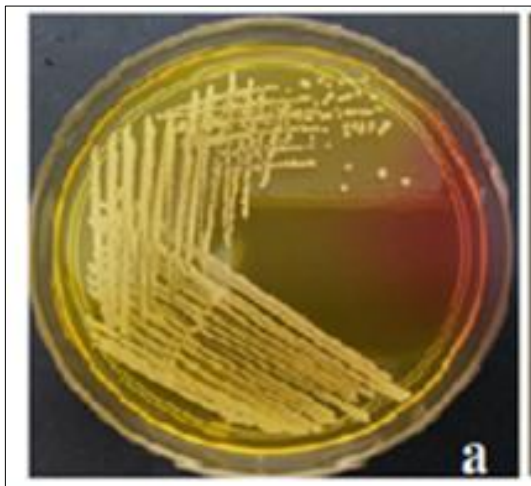

a) Staphylococcus aureus (mannitol fermentor) colony on MSA agar

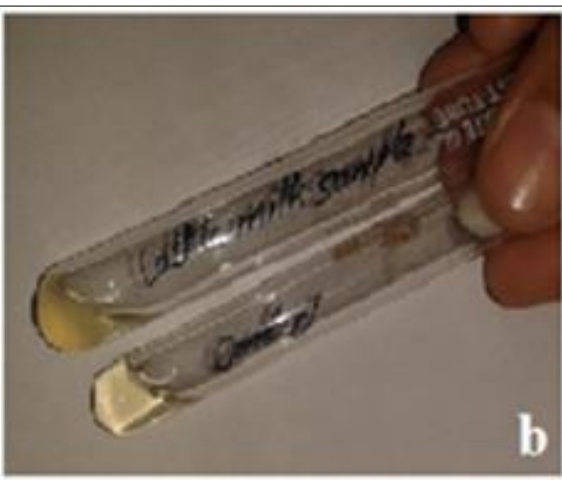

b) Coagulase test by Staphylococcus aureus

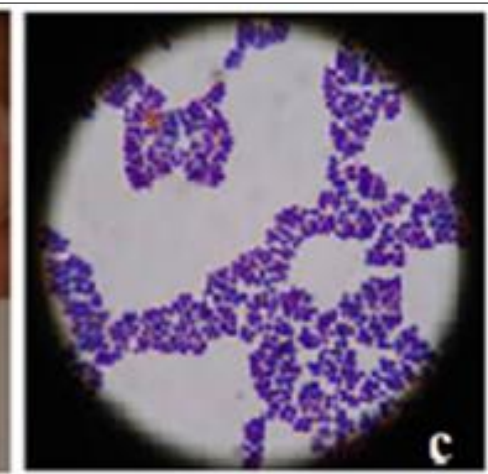

c) Microphotograph of mastitic milk showing Staphylococcus $\operatorname{son}(100)$

Fig 1.

The $85 \%$ isolates also produced hemolysis on blood agar (alpha and beta hemolysis in 4 and 13 isolates, respectively) (Table 2). The results of the present study are in complete agreement with that of Upadhyay \& Kataria, (2010) ${ }^{[28]}$ and Gangwal et al., (2016) [9] who recorded the haemolytic properties of $S$. aureus obtained from milk samples of cattle and goats. Total of $70 \%$ and $80 \%$ isolates were recovered for DNAse test, coagulase production (Figure.1) respectively and fermented different sugars (Table 2). Similar finding was reported by Kateete et al., (2010) ${ }^{[12]}$ who detected that $75 \%$ and $91 \%$ isolates of $S$. aureus were DNAase positive, coagulase positive in that order. Yadav et al., (2015) ${ }^{[29]}$ who obtained $32 \mathrm{~S}$. aureus isolates from cattle and buffalo and they all showed a strong coagulase reaction.

Table 2: Biochemical characterization of Staphylococcus aureus

\begin{tabular}{|c|c|c|}
\hline \multirow{2}{*}{ Test } & \multicolumn{2}{|c|}{ Positive } \\
\cline { 2 - 3 } & Number & percentage \\
\hline DNAse test & $14 / 20$ & $70 \%$ \\
\hline \multirow{2}{*}{ Haemolysis } & $17 / 20$ & $85 \%$ \\
\cline { 2 - 3 } & $4 \alpha$ & $13 \beta$ \\
\hline Coagulase & $16 / 20$ & $80 \%$ \\
\hline Mannitol & $20 / 20$ & $100 \%$ \\
\hline Trehalose & $19 / 20$ & $95 \%$ \\
\hline Lactose & $20 / 20$ & $100 \%$ \\
\hline Maltose & $18 / 20$ & $90 \%$ \\
\hline Sucrose & $20 / 20$ & $100 \%$ \\
\hline Arabinose & $2 / 20$ & $10 \%$ \\
\hline Raffinose & $1 / 20$ & $5 \%$ \\
\hline
\end{tabular}

Streptococcus agalactiae:- Streptococcus agalactiae prevalence were obtained in $25 \%$ samples. The result, obtained in this study was accordance with the earlier workers from India, who reported incidence of Streptococcus agalactiae in mastitic milk was $14.01 \%$ (Kuler, 2006) ${ }^{[13]}$. These isolates were showed dewdrop like colonies on Edward's medium, revealed utilization of arginine, positive for VP test, absence of hydrolysis of esculin and fermented different sugars (Table 3). Daignault et al., (2003) ${ }^{[8]}$ selected total of $295 \mathrm{~S}$. agalactiae isolates were showed positive CAMP reaction, not to hydrolysed esculin, $95 \%$ of the isolates produced a beta-hemolysis and 5\% were nonhemolytic. On Blood agar plates all isolates produced haemolysis. Our observations based on haemolysis are supported by the report of Bhagat et al., (2015) ${ }^{[6]}$. Streptococcus agalactiae was also studied for sugar fermentation activity viz. Glucose, sucrose, lactose, and utilization of arginine. This Streptococcus agalactiae isolate did not ferment arabinose, sorbitol, mannitol and raffinose (Table no.3). Our result was comparable to that of Al-kuzaay et al., (2013) ${ }^{[1]}$ sugar fermentation results.

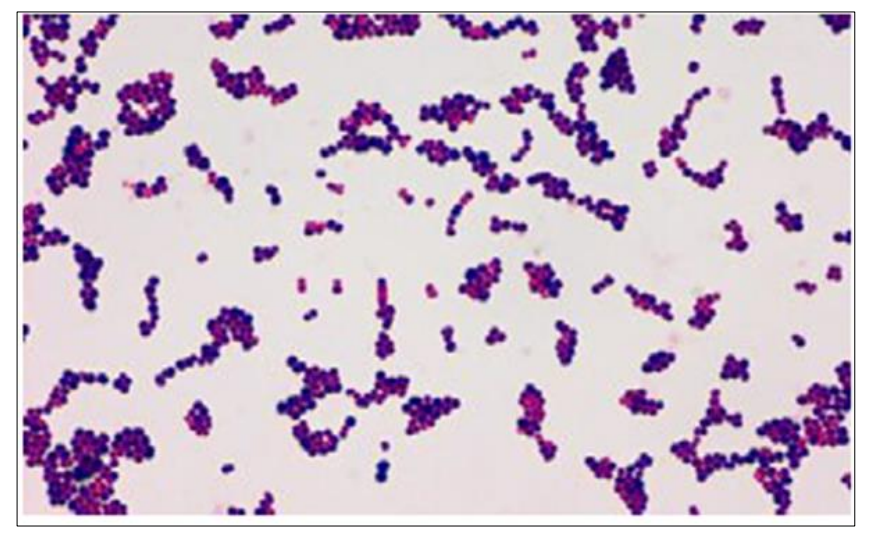

Fig 2: Microphotograph of mastitic milk showing Streptococcus spp. (100X) 
Table 3: Biochemical characterization of S.agalactiae

\begin{tabular}{|c|c|c|}
\hline \multirow{2}{*}{ Biochemical characters } & \multicolumn{2}{|c|}{ Positive } \\
\cline { 2 - 3 } & Number & percentage \\
\hline Growth on Edward's Media & $10 / 10$ & $100 \%$ \\
\hline Hemolysis & $10 / 10$ & $100 \%$ \\
\hline VP test & $8 / 10$ & 80.00 \\
\hline Esculin Hydrolysis & $1 / 10$ & $10.0 \%$ \\
\hline Arginine Utilizatation Test & $9 / 10$ & $90.0 \%$ \\
\hline Glucose & $10 / 10$ & $100 \%$ \\
\hline Lactose & $6 / 10$ & $60.0 \%$ \\
\hline Arabinose & $0 / 10$ & $0 \%$ \\
\hline Sorbitol & $0 / 10$ & $0 \%$ \\
\hline Sucrose & $10 / 10$ & $100 \%$ \\
\hline Mannitol & $1 / 10$ & $10.0 \%$ \\
\hline Raffinose & $0 / 10$ & $0 \%$ \\
\hline
\end{tabular}

Klebsiella pneumoniae: All 9 isolates of $K$. pneumoniae on preliminary identification showed biochemical characterization i.e. mucoid colonies on MacConkey agar with string formation, gram-ve rod shape in staining (Figure 3). These isolates revealed characteristic IMViC pattern (- - + + .), positive urease activity (Figure. 5) and growth on TSI (Y/Y/-) agar (Table.4).

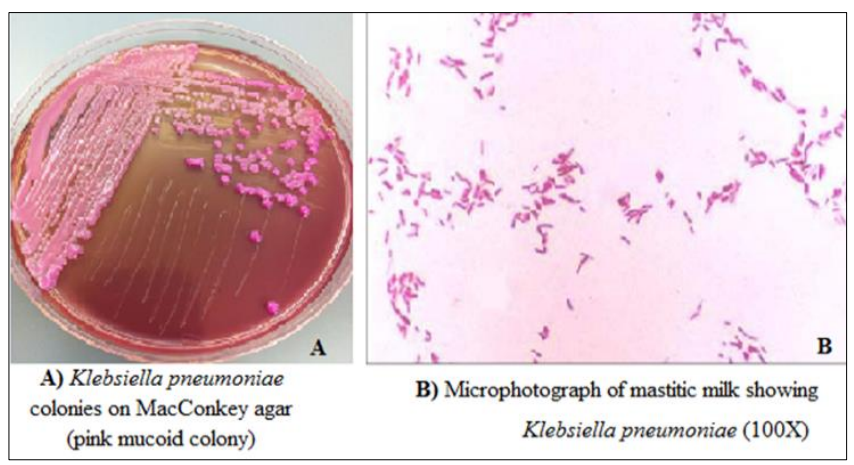

Fig 3.

Our result was similar with Alves et al., (2006) ${ }^{[2]}$ who reported that a total of 16 conventional and 4 supplementary tests were used to evaluate isolates identified as Klebsiella sp., out of these, $84 \%$ isolates were identified as Klebsiella pneumoniae that were negative for indole production, citrate positive, non-motile typical gram-negative bacilli, unable to assimilate histamine and d-melezitose or to grow at $10^{\circ} \mathrm{C}$.

Table 4: Biochemical characterization of K. pneumoniae

\begin{tabular}{|c|c|c|}
\hline \multirow{2}{*}{ Test } & \multicolumn{2}{|c|}{ Positive } \\
\cline { 2 - 3 } & No & \% \\
\hline Growth on Mac conkey & $9 / 9$ & $100 \%$ \\
\hline Indole test & $0 / 9$ & $0 \%$ \\
\hline MR Test & $5 / 9$ & $55.5 \%$ \\
\hline V-P Test & $9 / 9$ & $100 \%$ \\
\hline Citrate utilization test & $9 / 9$ & $100 \%$ \\
\hline Growth on TSI & $7 / 9$ & $77.7 \%$ \\
\hline Urease Test & $9 / 9$ & $100 \%$ \\
\hline
\end{tabular}

E. coli: All 8 isolates of E. coli on preliminary biochemical characterization revealed growth on MacConkey agar and produced metallic sheen on EMB agar (Figure 4). Similar finding was recorded by Leininger et al., (2001) ${ }^{[15]}$.

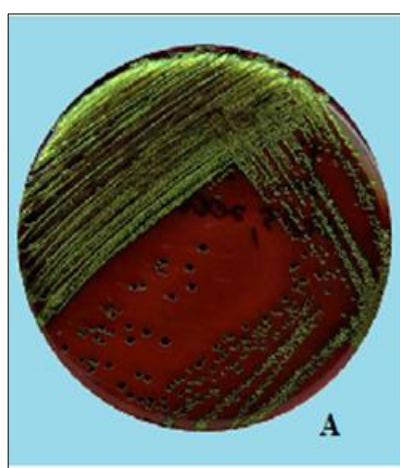

A) E.coli colonies on Eosine Methylene Blue agar

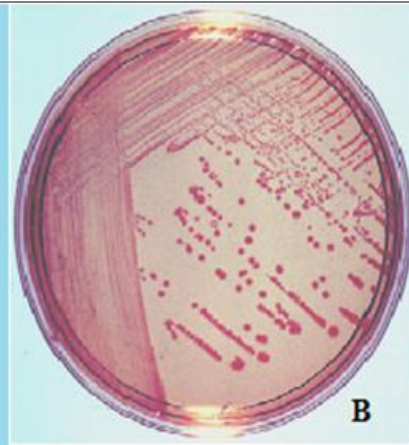

B) E.coli colonies on MacConkey agar

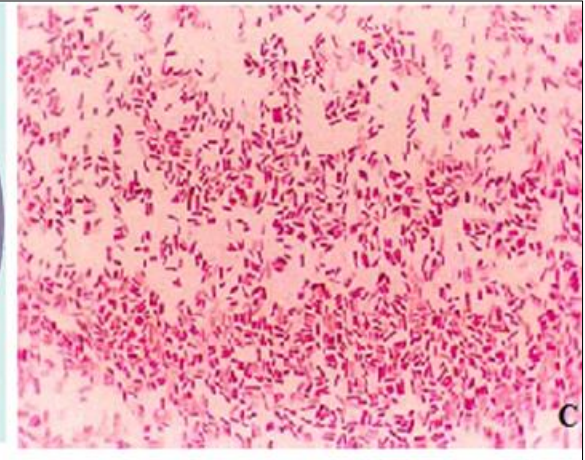

C) Mastitic milk showing E. Coli (100X)

Fig 4.

This appearance of metallic sheen on culture was due to the formation of eosinate from eosine. They all isolates showed characteristic IMViC $(++\rightarrow)$ pattern, and fermented different sugars (Table no. 5). They were also reported as Urease negative (Figure. 5) means not utilize urea and it is completely agreed with Rangel et al., (2009) [23] finding.
These findings nearly supported the Haque et al., (2014) [11]

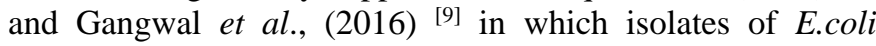
revealed positive reaction in MR test and Indole test but negative reaction in VP test and by fermentation of sugar they produced acid and gas. 


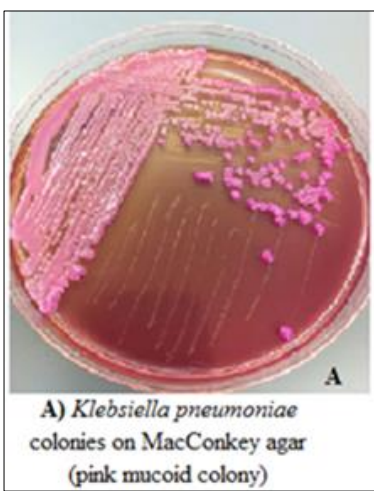

(pink mucoid colony)

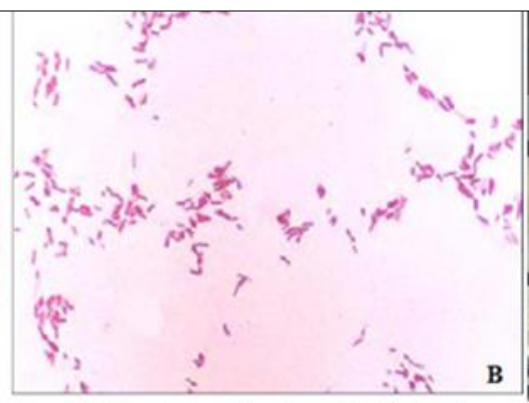

B) Microphotograph of mastitic millk showing

Klebsiella pneumoniae $(100 \mathrm{X})$

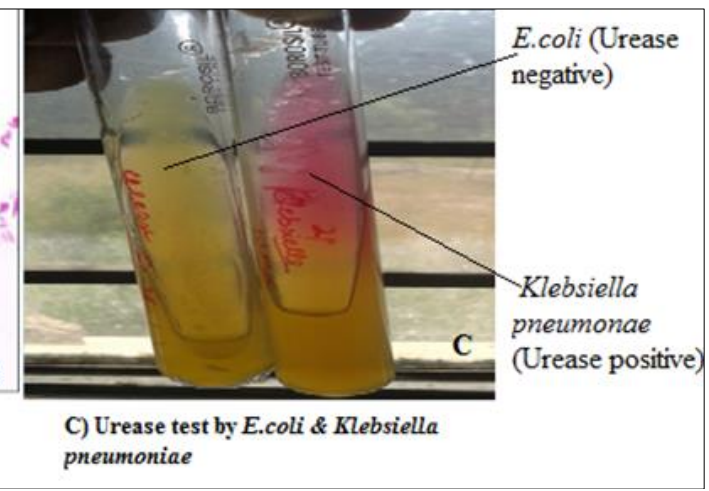

C) Urease test by E.coli \& Klebsiell pneumoniae

Fig 5.

Table 5: Biochemical characterization of E. coli

\begin{tabular}{|c|c|c|}
\hline \multirow{2}{*}{ Test } & \multicolumn{2}{|c|}{ Positive } \\
\cline { 2 - 3 } & Number & percentage \\
\hline Growth on EMB & $8 / 8$ & $100 \%$ \\
\hline Urease Test & $0 / 8$ & $0 \%$ \\
\hline Indole test & $8 / 8$ & $100 \%$ \\
\hline MR Test & $8 / 8$ & $100 \%$ \\
\hline V-P Test & $0 / 8$ & $0 \%$ \\
\hline Citrate utilization test & $0 / 8$ & $0 \%$ \\
\hline ONPG & $7 / 8$ & $87.5 \%$ \\
\hline Lysine utilization & $8 / 8$ & $100 \%$ \\
\hline Nitrate reduction & $8 / 8$ & $100 \%$ \\
\hline Sucrose & $6 / 8$ & $75 \%$ \\
\hline Glucose & $8 / 8$ & $100 \%$ \\
\hline Lactose & $7 / 8$ & $87.5 \%$ \\
\hline
\end{tabular}

Molecular diagnosis of common bacterial pathogens directly from bovine mastitic milk-The present study revealed that multiplex PCR method was very rapid and early detection tool to determine bacterial etiology of mastitis milk samples simultaneously at a time in single reaction with lesser reagents than simplex PCR, which was similar to that of earlier reports (Phuektes et al., 2001; Gillespie et al., 2005) $[20,10]$. DNA was isolated from 40 milk samples by method described by Phuektes et al., (2001) [20] with slight modifications. Results obtained from multiplexing showed simultaneous detection of $S$. aureus 25 (62.5\%), S. agalactiae 17 (42.5\%), K. pneumoniae 13 (32.5\%), and E.coli 10 (25\%). The respective pathogens were visible under agrose gel electrophoresis where amplified DNA fragments showed species-specific amplicons of size 264bp, 304bp, 555bp, $119 \mathrm{bp}$ corresponding to S.aureus, S.agalactiae, $K$. pneumoniae and E.coli (Figure.6). However, Shome et al., (2011) [25] were able to detect 10 bacterial strains simultaneously by mPCR. Azevedo et al., (2016) ${ }^{[4]}$ detected Coagulase Negative Staphylococcus, E. coli, S. aureus and other coliform bacteria (Klebsiella oxytoca, Klebsiella pneumonae and Serratia marcescens) in 100, 75, 59, and $35 \%$ of Bulk Tank Milk, respectively by mPCR.

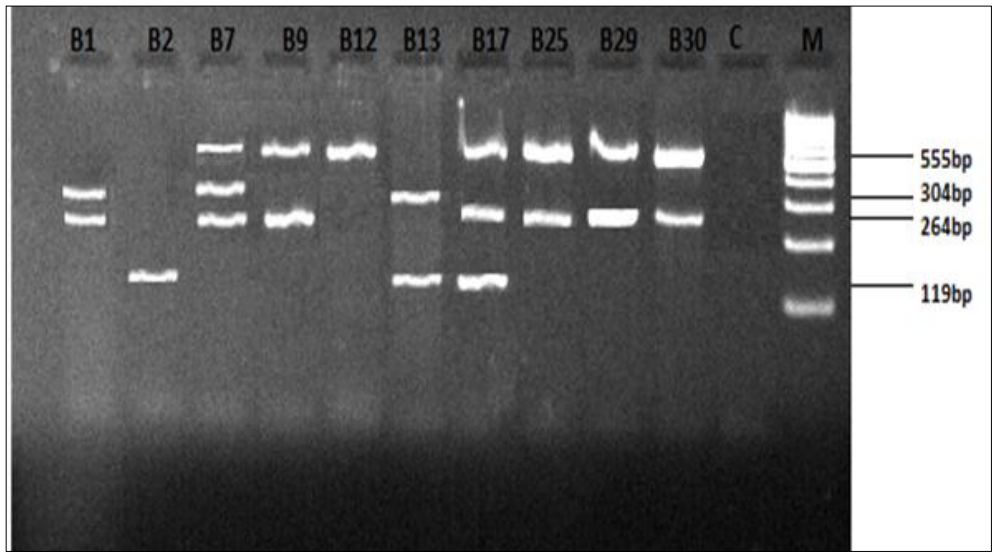

M- marker 100bp, C- control, B- sample no.

$119 \mathrm{bp}-$ E.coli, 264bp- S.aureus, 304bp -S.agalactiae, 555bp -K. pneumoniae

Fig 5: Sensitivity of multiplex PCR in direct detection of pathogens directly from milk sample

Differential Sensitivity of conventional methods and Multiplex PCR on Milk Samples Upon comparison, the multiplex PCR could detect more species at a time, from the DNA which was isolated directly from milk samples than that of conventional methods. In multiplexing all culture positive samples were detected positive for the corresponding bacteria (S. aureus, S. agalactiae, K. pneumoniae, and E. coli) but milk samples that were negative for these pathogens by culture method, found to be positive by multiplex PCR. The comparative detection of corresponding bacteria is depicted in Table 6 and Figure no. 6. In comparison of mPCR with isolation of the pathogens, the mPCR detected more isolates
( $n=65)$ as compaired to phenotypic determination $(n=47)$. The additional isolates were also detected by $\mathrm{mPCR}$ in 8 samples which were culture-negative for the corresponding species. Five samples were negative for both cultural isolations as well as from mPCR detection. A higher detection ranging from 2 to 7 was observed in MPCR when compared to culture for selected species. The probable reasons for the detection of additional organisms by $\mathrm{mPCR}$ might be due to non viability of the particular bacteria, which did not create interference in detection by PCR technology. Besides, the discrepancy in the number of different bacteria present in milk may be due to result in growth of the dominant species 
inhibiting the growth of minor species. In a similar way Taponen et al., (2009) [27] and Shome et al., (2011) [25] reported a large proportion of positive samples via molecular methods from culture-negative milk samples in conventional bacteriology.

Table 6: Comparison of detection of target pathogens in mastitic milk samples by multiplex PCR and culture

\begin{tabular}{|c|c|c|}
\hline Organism & Genotypic determination Number of isolates (\%) & Phenotypic determination Number of isolates (\%) \\
\hline Staphylococcus aureus & $25(62.5 \%)$ & $20(50 \%)$ \\
\hline Streptococcus agalactiae & $17(42.5 \%)$ & $10(25 \%)$ \\
\hline Klebsiella pneumoniae & $13(32.5 \%)$ & $9(22.5 \%)$ \\
\hline E.coli & $10(25 \%)$ & $8(20 \%)$ \\
\hline Total isolates & 65 & 47 \\
\hline Positive sample & 35 & 27 \\
\hline Negative sample & 5 & 13 \\
\hline Sensitivity & more & less \\
\hline
\end{tabular}

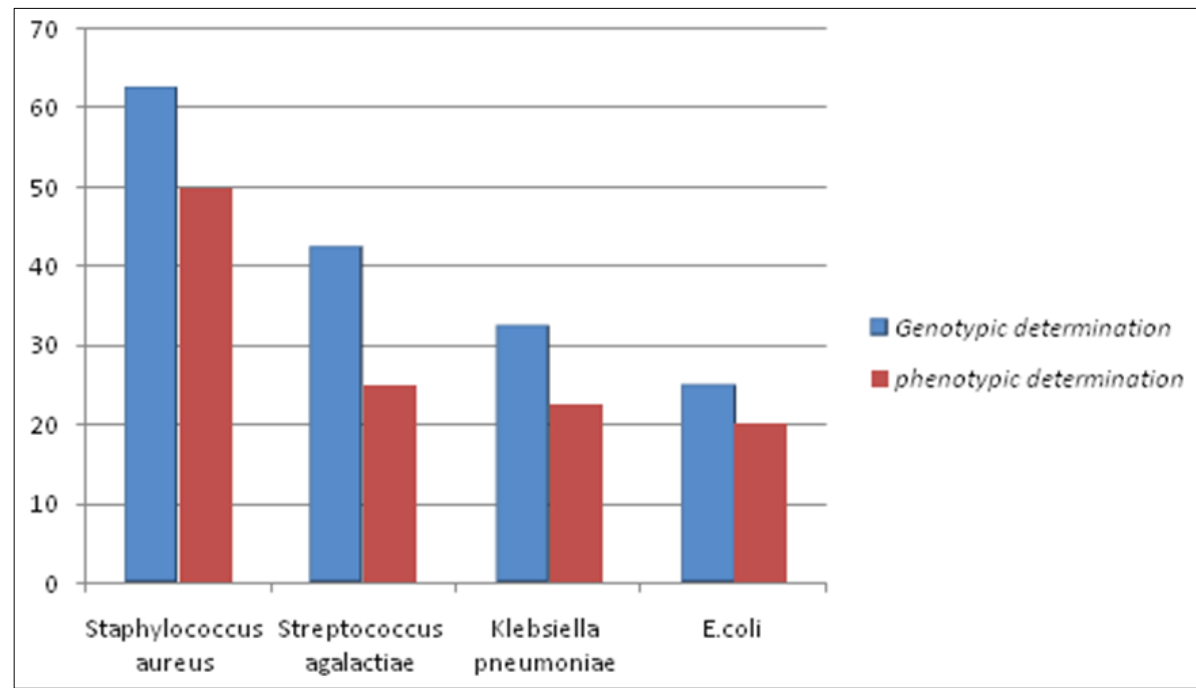

Fig 6: Comparison of detection of target pathogens in mastitic milk samples by multiplex PCR and culture

\section{Conclusion}

It can be concluded that DNA isolation and MPCR methods developed in this study are more sensitive and faster than conventional culture, and can be easily applied for detection of $S$. aureus, S. agalactiae, K. Pneumonia and E. coli in milk samples simultaneously. It can therefore be used as alternative to conventional culture method in the routine diagnosis. Early detection of mastitis by $\mathrm{mPCR}$ provide correct species identification at the initial stage and reveal exact etiology, furnish appropriate assistance or medical aid for the affected animal. It may, contribute a fruitful role in surveillance programs, prevention, control strategies and in epidemiological investigations. Also this study would be basis of further studies that aim to optimize and perform new processes for examining other bacterial agents that cause mastitis. In conclusion, the developed mPCR assay can be used for rapid, sensitive, specific and reliable identification of the major mastitis pathogens from milk.

\section{References}

1. Al-kuzaay GK, Kshash QH. Streptococcus agalactiae mastitis of bovine detection by Polymerase Chain Reaction (PCR) test in AL-Diwanyia province. AlQadisiyah Journal of Veterinary Medicine Sciences 2013;12(2):101-110.

2. Alves MS, Da Silva Dias RC, De Castro AC, Riley LW, Moreira BM. Identification of clinical isolates of indolepositive and indole-negative Klebsiella spp. Journal of clinical microbiology 2006;44(10):3640-3646.
3. Awale MM, Dudhatra GB, Avinash K, Chauhan BN, Kamani DR, Modi CM et al. Bovine mastitis: a threat to economy. Open Access Scientific Reports 2012;1(5):295.

4. Azevedo C, Pacheco D, Soares L, Romao R, Moitoso M, Maldonado $\mathrm{J}$ et al. Prevalence of contagious and environmental mastitis-causing bacteria in bulk tank milk and its relationships with milking practices of dairy cattle herds in Sao Miguel Island (Azores). Tropical animal health and production 2016;48(2):451-459.

5. Bannerman DD, Paape MJ, Hare WR, Sohn EJ. Increased levels of LPS-binding protein in bovine blood and milk following bacterial lipopolysaccharide challenge. Journal of dairy science 2003;86(10):3128-3137.

6. Bhagat GH, Kher AI, Dadawala HC, Chauhan BS, Shah NM. Isolation, identification and antibiogram of Streptococcus agalactiae Isolated from the Bovine Mastitis. Indian Veterinary Journal 2015;92(11):27-29.

7. Cremonesi P, Pisoni G, Severgnini M, Consolandi C, Moroni $\mathrm{P}$, Raschetti $\mathrm{M}$ et al. Pathogen detection in milk samples by ligation detection reaction-mediated universal array method. Journal of dairy science 2009;92(7):30273039.

8. Daignault D, Guevremont E, Guillemette JM, Messier S, Gottschalk M, Higgins R. Serotypes of Streptococcus agalactiae cultured from dairy milk samples in Quebec. The Canadian Veterinary Journal 2003;44(3):217-220.

9. Gangwal A, Kashyap SK. Identification of bovine mastitis associated pathogens by multiplex PCR. Journal of Dairy \& Veterinary Sciences 2017, 3(5). 
10. Gillespie BE, Oliver SP. Simultaneous detection of mastitis pathogens, Staphylococcus aureus, Streptococcus uberis, and Streptococcus agalactiae by multiplex real-time polymerase chain reaction. Journal of dairy science 2005;88(10):3510-3518.

11. Haque ME, Islam MA, Akter S, Saha S. Identification, Molecular Detection and Antibiogram profile of bacteria isolated from California mastitis test positive milk samples of crossbred cows of Satkhira District in Bangladesh. GSTF International Journal of Veterinary Science 2014;1:59-63.

12. Kateete DP, Kimani CN, Katabazi FA, Okeng A, Okee MS, Nanteza A et al. Identification of Staphylococcus aureus: DNase and Mannitol salt agar improve the efficiency of the tube coagulase test. Annals of clinical microbiology and antimicrobials 2010;9(1):1-7.

13. Kuler RN. Characterization of predominant bacteria from cases of bovine mastitis with special reference to genotyping of staphylococcus aureus. Doctoral dissertation, Karnataka Veterinary Animal and Fisheries Sciences University, Bidar 2006.

14. Kurjogi MM, Kaliwal BB. Prevalence and antimicrobial susceptibility of bacteria isolated from bovine mastitis. Advances in applied science research 2011;2(6):229-235.

15. Leininger DJ. Escherichia coli mastitis in the Dairy Bovine. Doctoral dissertation, Diss. Virginia Tech 2001.

16. Liu ZM, Shi XM, Pan F. Species-specific diagnostic marker for rapid identification of Staphylococcus aureus. Diagnostic microbiology and infectious disease 2007;59(4):379-82.

17. Martins MT, Rivera IG, Clark DL, Stewart MH, Wolfe RL, Olson BH. Distribution of uidA gene sequences in Escherichia coli isolates in water sources and comparison with the expression of beta-glucuronidase activity in 4methylumbelliferyl-beta-D-glucuronide media. Applied and Environmental Microbiology 1993;59(7):2271-2276.

18. Munari FM, De-Paris F, Salton GD, Lora PS, Giovanella $\mathrm{P}$, Machado $\mathrm{AB}$ et al. A combined enrichment/ polymerase chain reaction based method for the routine screening of Streptococcus agalactiae in pregnant women. Brazilian Journal of Microbiology 2012;43(1):253-260.

19. Oliver SP, Gillespie BE, Headrick SJ, Moorehead H, Lunn P, Dowlen HH et al. Efficacy of extended ceftiofur intramammary therapy for treatment of subclinical mastitis in lactating dairy cows. Journal of dairy science 2004;87(8):2393-2400.

20. Phuektes P, Mansell PD, Browning GF. Multiplex polymerase chain reaction assay for simultaneous detection of Staphylococcus aureus and streptococcal causes of bovine mastitis. Journal of Dairy Science 2001;84(5):1140-1148.

21. Qu W, Zhou Y, Zhang Y, Lu Y, Wang X, Zhao D et al. MFEprimer-2.0: a fast thermodynamics-based program for checking PCR primer specificity. Nucleic acids research 2012;40(W1):205-208.

22. Radostits OM, Gay CC, Blood DC. Hinchcliff KW. Veterinary Medicine. 9th Ed. WB Saunders Ltd 2000, 603-653.

23. Rangel P, Marin JM. Analysis of Escherichia coli isolated from bovine mastitic milk. Pesquisa Veterinaria Brasileira 2009;29(5):363-368.

24. Riffon R, Sayasith K, Khalil H, Dubreuil P, Drolet M, Lagace J. Development of a rapid and sensitive test for identification of major pathogens in bovine mastitis by
PCR. Journal of clinical microbiology 2001;39(7):25842589.

25. Shome BR, Das Mitra S, Bhuvana M, Krithiga N, Velu $\mathrm{D}$, Shome R et al. Multiplex PCR assay for species identification of bovine mastitis pathogens. Journal of applied microbiology 2011;111(6):1349-1356.

26. Taponen S, Salmikivi L, Simojoki H, Koskinen MT, Pyorala S. Real-time polymerase chain reaction-based identification of bacteria in milk samples from bovine clinical mastitis with no growth in conventional culturing. Journal of dairy science 2009;92(6):2610-2617.

27. Upadhyay A, Kataria AK. Haemolytic properties and titration of haemolysins of Staphylococcus aureus of milk origin from cattle and goat with clinical mastitis. The Indian Journal of Veterinary Research 2010;19(2):60-65.

28. Yadav R, Sharma SK, Yadav J, Nathawat P, Kataria AK. Typing of Staphylococcus aureus obtained from mastitic milk of cattle and buffalo on the basis of coagulase (coa) gene RFLP patterns. Israel Journal of Veterinary Medicine 2015;70(4):37-41.

29. Zadoks RN, Watts JL. Species identification of coagulase-negative staphylococci: genotyping is superior to phenotyping. Veterinary microbiology 2009;134(12):20-28. 